\title{
THE BELIEF SYSTEM OF THE PEOPLE OF KAJANG: A PERSPECTIVE IN RELIGION ANTHROPOLOGY Sistem Kepercayaan orang Kajang dalam Perspektif Antropologi Agama
}

Oleh: Basrah Gising*

* Dosen Universitas Hasanuddin Makassar

E-mail: Basrah_gisingfS)yahoo.com

\begin{abstract}
Indigenous peoples of Kajang is an indigenous community that inhabit Kajang subsdistrict in Bulukumba regency in South Sulawesi province. They adopt a belief system that called Jenne'Talluka'and Sambajang Tattappu. Jenne talluka means ablution water that never canceled, while sambajang tattappu means always remembering the God almighty one

Kajang Indigenous peoples, especially those inhabited inside kajang (inside Embayya) still embrace and keep up the belief system as mention above until now. Almost all of them do not carry out and shari'aand the pillars of the Islam: uttering syahadat (confession) words, establishing prayer five times and the Sunnah, fasting in Ramadan month, contribute to zakat, and fulfilling hajj worship.

I use the Anthropology of Religion approach to study the belief system of such Kajang community. Through this approach, I will be focusing on a system of worship and religious behavior of Kajang indigenous peoples.
\end{abstract}

KeyWords: Belief System

Abstrak

Masyarakat adat Kajang adalah sebuah komunitas adat yang mandiami Kecamatan Kajang Kabupaten Bulukumba propinsi Sulawesi selatan. Mereka menganut sebuah sistem kepercayaan Jenne 'Talluka dan Sambajang Tattappu, Jenne talluka artinya air wudhu yang tak pernah batal, sedangkan sambajang Tattappu artinya selalu mengingat Tuhan Yang maha Esa.

Masyarakat adat Kajang, khususny ay angber domisili di kajang Dalam (Ilalang Embayya) masih menganut dan memegang teguh sistem kepercayaan di atas hingga saat ini. Hampir keseluruhan dari mereka tidak ada yang menjalankan syariat dan rukun Islam: mengucapkan kalimat syahadat, mendirikan sholat lima waktu dan sunnah, berpuasa di bulan Ramadhan, mengeluarkan zakat, dan menunaikan ibadah haji.

Saya menggunakan pendekatan Antropology Agama untuk mengkaji sistem kepercayaan orang Kajang tersebut. Melalui pendekatan seperti ini, saya akan menfokuskan diri pada sistem penyembahan dan perilaku keagamaan masyarakat adat Kajang.

Rata Kunci: Sistem Kepercayaan

\section{The Myth of $T u^{\prime}$ Manurung in Kajang}

A mythology of Tu'Manurung, as well as in other ethnic group in South Sulawesi is also well known in the myth epoch of Kajang. Acding to Ammatowa (the customary leader of

- -ijang), that the first human being in Kajang called -he Amma (the first Ammatowa in Kajang) came iown to the earth of kamase-maseya (a full simpliccountry) and lived in Tanatowa (the customary $>$ rest). This forest region, at the first time is just alike an appeared land (tombolo') as wide as the leaf of umbrella (siraka' dohong). This small land is surrounded by the sea water and widened time by time match with the development of human on it. Even in the myth epoch of Kajang is stated that the development of Kajang region (rambang luara'nai Kajang) widened to the four wind direction, ie.: 1) North are Sape, Solo, Kaili and Salaparang, 2) East are Tambelu, Tambora, Ternate and Ambon, 3) South are Tanuntung, Tammatto, Bua Tana, Sangkala and Lombo, dan 4) West are Bajeng, Tassese, Kalimporo' and Manimporong. 
The places where the firts human appear in the myth epoch of pasang ri Kajang called Pa'rasangang (resident or village). The first place wherein is believed as the domicile of the first human beeing is the West resident $\{\mathrm{Pa}$ 'rasangang Iraja or Borong Iraja) opposite with East resident (Pa'rasangang Ilau or Borong Ilau). The first place is considered equal with Madinah Almukarramah in Saudy Arabia. Therefore the man who has conducted a customary ritual Akattere '(back to the holy spirit) take this place for pilgrimage. The second place is considered equal with PadangArafah (Arafah Plain) in Saudy Arabiah. It becomes as the second place for pilgrimage by the people of Kajang after conducted Akattere' and Addinging-dinging (the funeral or sorrow ritual).

Not longer after $T u^{\prime}$ Manurung arrival, he was then back to the heaven or disappear (Assajang). He borned, before five children include of one girl and four boys. His five children named Dalonjo $r i$ Balagana (the leader of Balagana region), Dangempa $r i$ Tuli (the leader of Tui region), Damangussalam ri Balambina (the leader of Balambina region), Dakodo ri Titaka (the leader of Titaka region), and Tu 'Mutung ri Sobbu (the leader of Sobbu region). The five chlidren of Bohe Amma have each social function and own region. They accept responsible to wispread their ancestor belief Pasang ri Kajang to all their followers as we can see untill now in the inner and external Kajang region.

After Bohe Amma diasappered, the people of Kajang live in two customary regions and two ways of live. The people of inner Kajang live with fully simple way (kamase-maseyya). They are not matrerealims, individualism and far from greedy life. The people of inner Kajang is not allowed to live in the lap of luxury, include the amazing tools such as handphone, guitar, $\mathrm{TV}$, radio, music instrument and so on. On the other hand, the people of external Kajang live with luxuriously style, fully materealism and individualism as well as the people of Bulukumba and surrounding region. Both areas are influented by the three current of Islam that are brought by the delegates who studied Islam in other place. Inner Kajang, for example, is more influented by Janggo' Tojarra's Islam comprehension who studied Islam from the Kingdom of Luwu by Datuk Patimang Sulaiman. He studied the creed sentences (Kalimat Syahadat) or God wishes to the prophet of Muhammad (doang rasulung). This comprehension of Islam is focused to the ritual of the life cycle as; birth day, circumcision, wedding, death ritual, move to new home, give obligatory alms, grand opening of trade, slaughter etc.. Other comprehension of Islam was brought by Janggo Towa (The son of Bohe Amma) widespreaded in inner Kajang. He studied mysticism version from Datuk ri Tiro nicknamed Abdul Jawad Khatib Bungsu in Bulukumba Kingdom. Other comprehension of Islam was brought by Janggo' Panrita nicknamed Toasara Daeng Mallipa widespreaded in external Kajang only. He studied the rules of Islam (Syariat Islam) in Gowa Kindom from Datuk ri Bandang nicknamed Khatib Tunggal Abdul Makmur.

The three above Islam coprehensions characterize the daily life of the people of Kajang (inner and external). The people of inner Kajang is not allowed to live with luxerious style, because one of the rule of Islam (led by Moehammad prophet) encourage the simplicity life of his follower. The people of inner Kajang are influeced by the Sufie and Tasauf that advocate the direct and closely relationship with God (Transcendental) and a simply live. The most important in Kajang belief is remember to the God forever (A 'ngurangi Tu' Rie' A 'ra 'na).

\section{The Religion and The Belief System in Anthro- pology}

\section{a. Some Studies of Religion And Belief System}

Anhtropology, after knowledge revoultion be happened, is fully developed in vary studies. The Anthropolog's attention for the religy system grew up quickly, especially for the religious ritual in a certain ethnic group. Even if this ritual at the beginning is just considered as an unique thing only, but at the end they formulate this characteristic religion as ittobe (emic) and try to bulk a theory of the liniage of religion.

Far before anthropology became as a body of knowledge, some ethnographer tried to write some characteristic of the local tradition which was too different with their own (Erqpean tradition). They used generally the ethoceSi'trism paradigm (seen other culture is worse than his own) brought religy and belief system as centre of their study.

The religion, or the belief system study in Anthropolgy is focused-to the religious behavior related to the tfaHy live of its followers. Anthropology of religion, in principle, will not study over the dogmatism of religion and belief system. This means that the anthropology of religion, for instance, will have never studied how moslem do worship but why they do it. 
A big question will be appear herein why the huan belief to the misterious thing as the most high evel of status than the human being ? Why human try ": communicate and looking for connection with that - sterious thing ? To unswer this question Anthroplogy :: religion must conduct a study for religy and knowledge system. According to anthroplog that the human 'c.igious activities is always based on trembeles of soul (mood) or religious emotion that is mirrored in r.eir religious activities or behavior. They believe that

- $a$ someone is in absolutely atheis but he must has

had a secondly feeling with this religious emotion. It will urge the human to conduct his religious ..tivities. The high frequency of mood can appear '."e unusually value form (sacred), whereas the low

e can appeare the usually value (profane) only.

The religion follower in certain culture must try Keep his own religious emotion. It is more important -"in the three other thing, ie.: 1) convincing, b) relig: :us rituals, and 3) the follower of a certain religion.

iropolog are generally pay their attention to the -"gels (good or bad) in cosmogony comprehension, the gost, the high level angel and the creator of nature " cosmology comprhension, and the live, the death ir.d the spirit of the world and the hereafter in the $\mathrm{c}: \mathrm{h}$ comprehension.

The religious ritual consist of the places of reli- ous ritual (temple, casle, church, mosque etc., the me of religious rituals (time for worship, sacred days,

ly days etc.), the tools of religious rituals (holy stat-cs. holy bells, holy flutes, holy drums etc.) and the

ef of religious ritual (pastor, bishop, priest, shaman L-.d medical man or woman etc.). The ritual or religious ceremony has also many froms: prayer, song : $r$ prophet of Muhammad, slachting animal, meal to-ether, dancing, singing, procession, drama flatform, isting, trance, Yoga, and mediatation. These activies are expected to set themselves closely to their od and get the God bless.

\section{". The Symbol in Religion And Belief System}

According to Clifford Geertz (1992: 5) religion is - symbol system to appear mood and encourage strong motivations to achieve the human goals. It would be implied in all their religious behavior. Paull Tillich (1955) s adopted by Geertz's in his analysis obout the -eletionship between the meaning and the religion. Both f them (Geertz and Tilllich) take the meaning as a . mcept of their analysis over the absolute meaning, .e unity of meaning and Import. Import is sometimes called as the absolutely of meaning, the unity of deeply meaning or the meaning of the meaning (Paull Tillich (1955).

Geertz himself trend to equalize between religion and culture, because culture can be considered as an abtastraction of religion. According to him culture is a pattern of the meanings that historically is transfered to the symbols whereby human can communicate, sustain their world view, knowledge and attitude of life. It is very clear, by this concept that religion is a symbol and culture is as a patteren of meaning wherein are accumulated the representative and the absolutely relationship between abstract thing (culture) and concrete thing (religious behavior). So, religion is a realization of certain culture. Therefore religion withouth culture as the meaning giver is impossible and the culture withouth religion or belief system as symbolizer is also absolutely impossible.

McGuire (1992: 11-14) found two religious comprehensions called substantive andfimgtionalism. The concepts of substantive is the supernatural reality, the superempiris reality, the transendence reality and the sacred cosmos. On the other hand, the concept of functionalism is the relation between religion and culture. That concept found by Sapiro (1966) as an institution, the cultural pattern and the cultural postulate. This concept can be improved tobe superhuman being which is powerfully than human being.

\section{c. The Relgion, Belief System and Culture}

The closely relation between religion and culture encourage anthropolog to conduct a great study in his own specification or discipline. E. B. Tylor (1913) and G. J. Frazer (1976), for example, promote his concept over supernatural of some primitive societies. The belief system in form of spirtualism show how the first step in the evolution of human brain had been happened. That's why Tylor saw religion is alike as magic, because both are built by unempirical ideas or dogmatism.

Frazer, on the other hand, is different with Tylor who trend to saw religion is different from magy. The magy is always concern with magic power (bad spirit), otherwise religion is concern with supernatural (angles). Therefore, the improving of religion ( $\mathrm{dog}$ matism, dynamics and trancendental) is better than the magic (impersonality, statics and universalism). The well conducted of magic ritual for rainy requesting, for example, accomplish with the slachting animals may cause the rain fall. But when a pastor or other 
expert in religion, on the other side, prayer for the rainy request is not a guarantee for the rain fall, because its basic is just an expecting only.

Emile Durkheim (1964) and Mircea Eliade (1959) claim the above dogmatism supernatural concept by Tylor dan Frazer. Both of them consider religion as a sacred thing and not all it must be concern with supernature. Eventhough both experts have the same concept and paradigm about sacerd and profane, but in their aplication is still contradict each other. Durkhiem las well as Tylor, Freud and Frazer seek religion as funcionalism thing, whereas Elliade see religion is as a phenomenon (phenomenalism). Durkheim see religion as sacred thing in relation with society and his needs. Therefore the sacred means a sosial matters and profan is an individual matters. On the other hand, Elliade has never found the relationship between sacred thing and social phenomenon, except the supernature only, because it is always equal with the spirit or God.

E. E. Evans Pritchard (1956) showed how the religious concept of Nuer tribe influence the whole of their way of live. He found an absolutely dogmatism concept Kwoth Nhial (absolute God) as in supernatural comprehension. He lives on the heaven, but he is not alike as heaven. He is alike wind, but he is not wind. He represents all things, but he is abstract. He is considered as the leader of the angels Buk (women angel), Wiu (clan angel), Deng (the son of God), Mani (war commander) and Colwi (holy spirit) but he is not an angel. Pritchard then show how Nuer tribe devide his cosmology view in three stages: upper world where Kwoth Nhial and Kwoth stay, middle world is the place where the human life and under world wherein the sacred animal or the totem of human life.

Sigmund Freud (1953 and 1978) in his phsicoanalysis said, that the activities of the religious men is alike as the neurosis (terrance, mad or stress men) behavior. Therefore, someone will be feel wrong if he unperfectly follow the ritual worship. He also claim that the religion is an unempirical and is not given by God, because no scientific methode can be proved it. The religion isalso not less just as the strongly, the powerfull and the old expectation of the human needs. Therefore, the secret power of religion is just lay in the power of human expectation (illution) and not on their belief system. Ludwig Feurbach (1957) support it and said, that the religion is just as physichological tool to reinforce the expecting, the goodness, and the idea to achieve supernature comprehension called God. By this way, the human just tiy to put himself in the lowest status than it.
C. Jung (1938 dan 1972) refused the two concepts above and said, that religion is a collective human idea and is embeded in the mythology, folklore, philosophy and arts. The religion is appeared from collective unconsiusness and it is not as neurosis behavior like Freud and Ludwig see. It is appeared as helthfully, deeply and sustainable expession from human being and not appear from the neurosis statement of frustation. Max Weber (1951 and 1958) as well as Jung also refuse the neurosis concept of psychology and said that the supernatural belief is an universal fact that can be found in all primeval society. The religious behavior has never been lost from human daily activities to achieve his certain economic goal and needs. He conclude that the men involve magic expert (shaman) to seek the individual, sacred and dominant thing, otherwise use the priests (pastor, magical man/women, pastor, bishop, etc.) to look for the cooperative, profane, full authority, and fully religious etics.

\section{The Belief System of Customary People of Kajang}

The people of Kajang, especially inner Kajang still hold their ancestor belief called Jenne 'Talluka and Sambajang Tattappu. Both religious concepts are put in an oral tradition called Pasang ri Kajang (the message of ancestor) to the follower for applying in their daily life. The basic message of Pasang ri Kajang is the faith to Tu'Rie'A 'ra'na (the creator) who give a guidance (tuntungan) in the social interaction between the followers. The role and occupation of Tu' Rie' A'ra'na is alike as Kwoth Nhial in Nuer tribe belief, Puang Matowa in Tator belief, Dewata Seuwa 'e in Buginese-Macassares belief and many other kinds of believes in Indonesia.

Every house, especially inneer Kajang has a small fully earth water butt in the left side of the ladder. This water is used by the guest to wash their leg, mouth, hand and face (ritual washing) before come upstairs the house. A house for Kajang people is believed as a sacred thing', sothat everyone who wants to come upstairs in it must clean his body and spirit before. There are four meaning of the activites in ritual washing, ie.: First, abbisa lima yamintu appabajiki palampa limayya nuanre kaalle-alle means wash your hand for not stolen. Second, abbisa muka yamintu appabajiki bua matayya nuanre kitte-kitte means wash your face include your eyes for not seeing bad thing. Third, abbisa timuyamintu appabajikipassulu' sa 'rannu nuanre kabica-bicara means wash or clean your mouth for not saying uncorrect thing (laying). 
north, abbisa bangkengyamintu. appabajiki angka' 'jngkenga nuanre ka'lampa-lampa means wash your leg for not going anywhere to do bad thing (sin). This four matters must always keep and do it after uri" iied. strncky wind and? lost feces for not breaking their - $r^{\wedge}$ al washing such as the rules of the treatment of ritual - ashing in Islam. The body and spirit clean is the most $\sim$ portant in the people Kajang's worship.

The comprehension for Sambajang Tattappu -ealize fn their transcendental activities to Tu'Rie'

$n a$ in every time. The God reminding is very -portant for the people of Kajang's life to himself :!ose to the holy God by the five ways: First, punna gkako sompoi Karaeng Alia Taalanu means "oke your God to your shouder when you are walking. .. ond, punna cidongko rihai Karaeng Alia Taalanu means hold your God in your lap when you ire seating down. Third, punna tinroko raka' jrambdngngi Karaeng Alia Taalanu means embrance your God when you are sleeping.

The belief system of the people of Kajang set $T u^{\prime}$ Rie 'A 'ra 'na (God) as a form of macrocosmos from other $\therefore>$ moses. There are some hierachies of cosmos in the xopte of Kajang's belief. They believe that Pasang ri 'Lijaiig is as medium of the guidance (annuntungi) to all reople of Kajang. It is as a microcosmos from the high :osmos of God and macrocosmos from low cosmoses >ich as Ammatow ri Kajang, Tu'Mutung (the agent of Ammatowa), the nature and Tu'Mabbutayya (the people :f Kajang). Ammatowa is microcosmos of the above - smoses and the macrocosmos of the low cosmoses and so on as can be seen in below diagram:

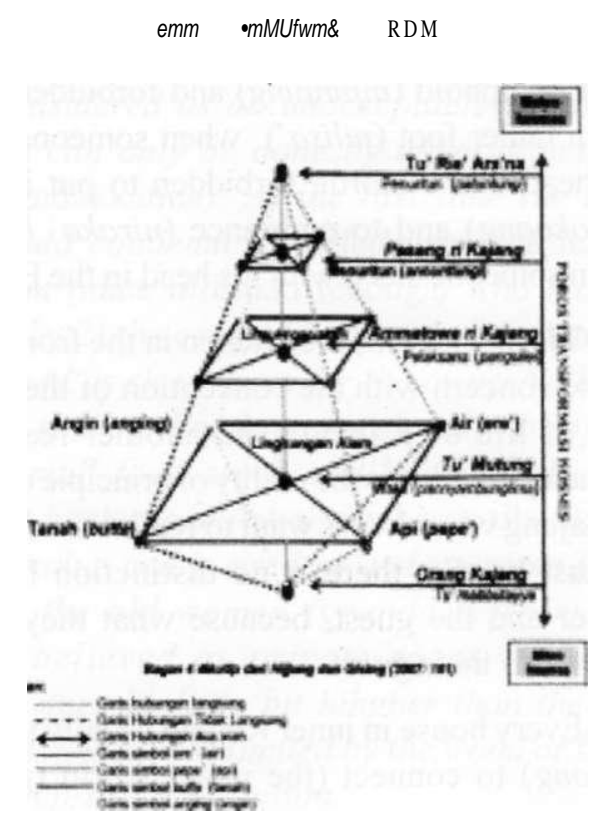

lurnal "Al-Qalam" Volume 17 Nomor 1 Januari - Juni 2011
The diagram show the transcosmic pattern from the lowest cosmos of the people of Kajang (Tu' Mabbutaiyya) to the highest cosmic of the creator (Tu'

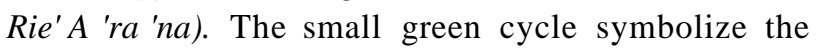
centre point of cosmic consist of four matters: fire (apt) is symbolized by small red cycle, water (ere') by small blue cycle, wind (anging) by small yellow cycle, and earth (butta) by small black cycle. The four angles symbolize the cosmology of the people of Kajang for this wolrd. They consider that this wolrd is plately such as the four angle (sulapa' appa'na linowa). The four angles of the world, according to the people of Kajang's perception, reperesent for the important matters (fire, wind, water and earth) in human and nature creation process. This conception is actually different from Colombus who found this arrounded wold.

\section{The Cosmology of Kajang People}

The way of life of the people of Kajang, especially inner Kajang is reflected in his daily and simpilicity of life (kamase-maseyya) pattern. This simply principles is more accumulated in their cultural knowledge (what people know), their cultural artifact (what people create) and cultural behavior (how people react), as below:

\section{a. The Perception of Color}

The simply living of the people of Kajang give a color to the whole of aspects of their live, include their daily cloth ${ }^{2}$ which is color (black), materials (nature) and its proccess (traditional) very simple one.

The black color is the favorite color, either in inner Kajang or external Kajang. The black color has special meaning as a collected of some basic color. It symbolize calmful, peaceful, pleasure, silent, safety and great motivation to face the problems of live. It is also considered as the oldest color that symbolize the mature of thingking and all at once symbolize the simplicty of life.

The black color is drawn in Pasang ri Kajang, that Anre le Jeng tua, anre le Jeng lolo, anre tongi le'leng situju-tuju, mingka le'leng lambusu'ji means that the black color can not be devided into strong black, weak black and bright black but dark black only. It is different from others color (yellow, blue, red) that can be devided into strong yellow (didi towa), weak yellow (didi lolo), strong blue (moncombulo towa), weak blue (moncombulo lolo), strong red (eja towa) and weak red (eja lolo). The black color is concern with the earth color whereby the first human being (Adam) was built. 
The appearance of the black color tobe a favorite one in Kajang's customary territory is more concerned with their way of life. According to their perception that the first and last color that we meet in our live is black. The black color met when we were in our mother's lap and also will meet in our death later. As long as nine month in our mother's lap just met the darkness, before we born to look the world breatness (angngitte tajang ri linowa). To proof it someone request me to close my eye and ask what I can see ? By this way I can see nothing, except the darkness. It proof that black is a basic color of all deviations. The perception of Kajang people draw that nikua ruajintu halo iyamintu le Tenga bajanganna bangngiya nakebo ' bajanganna tajanga iyarega allowa means there are just two kind of color the black is a repsentation of the night darkness and white is replica of the day brightness. The Black color is also a symbol of a simply life of inner Kajang people and white is a symbol of luxurious life of the external Kajang people. Eventhough the people of Kajang do not refuse other two color except balck and white. The red and yellow are always presented in the cone of the boiled rice (kukkusu'). The two color of cone rice (kukkusu' ruanrupayya) present black as a symbol of the earth and white as a symbol of water, whereas the four color of cone rice (kukkusu' patanrupayya) present additing color yellow as a symbol of air and red as a symbol of fire.

\section{b. The Meaning of House Construction}

The house as a cultural artifacts is built based on the cosmology of Kajang people. All processing of the raw materials preparing, the house construction, the rooms order and the time of buliding a house must be based on the manners and the rules in Pasang ri Kajang. None can built a house without consultation with the expert (uragi bold) who has magic power and many experiences in a house building.

The using of nails and other metals, especially in customary house of Ammatowa is strongly forbidden kasipalli, talama'ring or karrasa'. This prohibition is concern with their perception over the plant right. All of the wood materials in a house building is considered has the right and still life as well as the tries in the forest. Therefore the using of metal goods believe can hurt the wood materials, because the nail or other metal goods is believed can hurt it. This draws that the people of Kajang respect to the rights of other organism, include the plant right.
The roof is made from palm leaf which is knitted on a small lath of bamboo (paninting). The usage of zinc roof or other artificial roof is strongly forbidden in inner Kajang. According to the mythology of Kajang that rie' serre hattu naballoi bolanu nahambangi kalennu means in one time your house is beautiful but you will be feel very hot. This message consist of a forbidden to use zinc or other kinds of roof. It is believed can polute the air and increase the pressure of the surrounding atmosphere. Other people said" that the other consequences of the using of unnaturally sine roof is make the wild frighten and go away from the forest.

The floor and wall is made from a small lath of bamboo (salimara') that is plaited on a basic frame. It must be veretically plaited, because bamboo is considered already die sothat it can not stand anymore. The space of the floor is bordered by the wood block $\left(k o k k o^{\prime}\right)$ to stand the small beam of floor (hallusu') wherein the lath of bamboo of floor (dassere') is fastened with rattan. No chair, table, sping bed and so on be allowed on this floor, except the palm leaf and the ratta mat for seating and sleeping. The*e is a strong of this lanaiki mai ro bola anre jalli na tappere sangkammai mase-maseya means come upstairs the house please. There is nothing at all we are very poor.

The ladder is commonly shoot out and stand in the right side of the house, where the door (anna') is placed opposite whith the kitchen and the small toilet. This position of ladder concern with the head posisition of someone when lie down or sleep in the house. The head must be always positioned in South and is strongly forbidden in North, East and West position. This position concern with the sacred customary forest which is spreaded out in East and West of the village. Both places must be uphold (nijunjung) and forbidden to trample down under foot $($ nilisa') when someone sleep with his head in the North, forbidden to put in back side (nibokoang) and to embrance (niraka' barambang) when someone sleep with his head in the East or West.

The position of the kitchen in the front part of the house concern with the conception of the simplification of life of Kajang. The another reason of this kitchen posisition is the reality of principle of the people of Kajang who always want to realize everything what it must be. So, there is no distinction between the owner and the guest, because what they eat is also offered to their guest.

Every house in inner Kajang usually use the prow (anjong) to connect (the upper world (langf) as a 
.-- ;osmos and the under world (lino) as micro-

" 5 This prow is commonly represent the dragong : e'iiel ed by the people of Kajang as the heaven kjpper. When the moon eclipse (allingo bulanga) - irpened. for example, the people of Kajang;s belief ifim the moon has been swallowed by the big dragon. . r:oll is sometimes is made from the bufallo's $s \backslash$ mbolize their economic capability. This sym-

- : ze the capacity of owner when he conducted a $\sim$.ary ritual wherein a bufallo was slaughtered.

The division of house into three spaces tobe apcvr balcon (para bola), the body of house (kale and beneath of house (siring) is also con-

- with the cosmology of the Kajang people. These rooms order are connected with the three -"sis of the world: the heaven, the world and the world. The upper balcon is believed as rep-isentation of the heaven (boting langi'j, so this place must be a private and a sacred space and $\wedge$ bidden haphazardly to entere. The upper balcon - as well as the upper world wherein the angles Jid Tu' Rie' A'ra'na stay — is also belived as the see for the queen of rice (sangiasseri). None is silowed to entere it, except in the ritual for putting rice 'appanai pare',) in it. Even sometimes draw that ".ere is a cannibal grand mother life there to Tighten sombody or children to enter it.

The body of house (kale bola) is considered as - 'epresentation of the wolrd where social interac$:>n$ can be happened. It is devided into three :paces: 1) the front space of house (latta' riolq) opposite with the kitchen and is used as guest room. They are not allowed to enter the centre space of wuse without permission of the owner. This mis-.V is considered as an unacceptable action, bemuse this can only be done by unpolite man (tu' in re pangadakkanna). At the last time the house -mer could condemn or killed someone without rosecution (mate nilisakki tedongaj who has broken the rule, 2) the centre of house (latta' ritengnga)

functioned as sleep room for the owner with their carriage son or daughter (neolokal). In oppsite land a small food stock and kitchen toll stock, and 3) the back space flatta' riboko or tila-tila) has - special value and is used as a sleep room for the j"'75 and the old women (granda mother). This race is believed as private room, sothat the rosisition must be little bit hihgher than the other aces. It is sometimes limited by the wood or bambu wall to keep its privatitation.
In the middle row of the pillar stand a special pillar as benteng tangnga (the centre point of house). This pillar is believed as medium to connect the under world and the upper world. Therefore many of the customary rituals for fedding the house sprit a a 'nganro and appangtmro kacucu bold) use this pillar as a center of activities. To add its sacred value, this pillar is sometimes carved and wrapped with black cloth. It must be a perfect wood (kaju ganna' suka 'na), because straight, no stinky wood eyes, no hole, stink wood nucleus, form eight sides and old enough. This means that it has a mana* (bola haji sissi 'na) and can give a good inspiration to the owner. The imperfect house (bola kodi or bola patula) is believed can give calamities to the owner, because the pillar is considered unperfect.

Outside in the right, left and behind posisition, exactly on the top of wall side is built the bamboo bench (para-para) for the houshold storage on the left side of house for the bad room equipment storage on the right side of house, and for the heritage of the owner storage on hehind side of the house.

The top roof of the house \{timba lajara') is almost has no meaning as well as Bunginese and' Macassar, because there is no social stratifications in the customary of Kajang territory. That means that there is no stratification because no slave (Anre'Atd) and no aristicatic (Anre'Karaeng) in Kajang. It is made from palm leaf and is supressed by the knitting of some bamboo laths. This symbolize the structure of Kajang customary institutions ie.: Ammatowa ri Kajang is one person symbolized with one kintted lath, Karaeng Tallua are three persons with three kintted lath, and $A d a^{\prime}$ Limaiyya are five persons with five kintted lath.

The crossing of bamboo laths connects the four corners of the four angel as the symbol of the brotherhood and the unity of Kajang's people \{Assikajaneng). The four corners symbolize the four corners of the world \{sulapa' appa 'na linowa) and the four elements such as water, earth, air and fire that uesd to create the world and human beeing are connected in one centre point called life \{Katallassang).

\section{Religious Behavior in Customary Rituals}

Almost all religious behavior is paralelled with the conducting of the customary rituals. According to Koentjaraningrat (1992: 252) that sometime the human faces his magic world with various feelings: not 
just love, respectation, and loyality, but also fear, shudder and so on. This feeling encourage the human to do some religious activitaties (religious behavior) for seeking the connecting with that magic world. The interest of the people to conduct a religious ritual is urged by the mood (ritual emotions) which is appeared from the various feelings. These are then realized in a form of religious ceremonies or rites. The appearing of the process of feeling sympton become a form of emotional spread which then tobe a thanks giving or request by the religious rituals.

There are some important elements in the ritual conducting are ritual place, ritual time, medium of ritual and ritual conductor. All these elements represent or symbolize the purpose and the goals of the customary ritual.

The customary ritual in Kajang is generally take three places: 1) in the customary house of Ammatowa ri Kajang called a ritual for worship and helth request (A 'nganro), 2) in the house of the people of Kajang called back to the purity of spirit (Akkattere'), the realisation of vow (appanganro kacucu bold), the protection request to the God (addingi-dinging), the thank God ritual (abbogoro), the birth day ritual (attompolo), the tooth grind ritual (akkalomba), deth ritual for the low class people (a 'dampo lajo-lajo), deth ritual for high class people (a'dagang), and 3) in the sacred customary forest (borong karama').

The customary ritual is generally conduct based on the value of the symbol, the sacred thing value, the ceremonial value, and the thank God value. The ritual of Akkattere', for example, is more concerned with a ceremony based on the value of the symbols. The men who can conduct it is considered has a capablity to conduct one of the Islam orders called black pilgrimage (aji le 'leng). This term is connected with the daily balck cloth as their uniform. The place for hair cutting is conducted the four angels bamboes fence (badi'). It look alike Qa'bah in the mosque of Maccah AlMukarramah. The ritual of akkattere can increase the economical status of the owner and leveled with the man who has been to Maccah to do pilgrimate.

One of the customary rituals is the ritual of the election of Ammatowa ri Kajang (pa 'nganro annyuru borong). It is considered as holy ritual because Tu'Rie'A'ra'na believed attend it. All people of Kajang collect together in Borong Balagana (Balagana forest) to attend and to watch directly the processing of Ammatowa election.
The thank God ritual which is conducted after paddy harvest in the ricefield. This ritual look alike as the mappalili (walk aoUrnd the ricefield) ritual by Barru and Soppeng people and Mappamula the beginning of paddy harvest) in Karampuang customary people (Gising, 2005: 122) or panen perdana in Indonesian language. It take places in the customary house of Ammatowa and in the ricefield. It is commonly conducted when the sun is coming up (langkasa'mi allowa) or about 10.00 am.

The memorial ritual is a customary ritual to remember their deth family. It is generally conducted in the night ( $A$ 'ngalle Bangngi) at the sorrow house and based on the day of the deth. It will be accounted from the first, the third, the fifth, the seventh, the fifteenth, foutieth, fiftieth, seventieth, eightieth . ninetieth and hundredth. This counting is related with the journey of the deth men. At the first night is believed that the spirit of the deth is still stay at home. The third and the seventh night is consider the deth man start to the journey to another world (alio riboko). The fiftienth upto hudreth night is believed that the deth men is to far from this world and almost finish his journey to paradise for the good men (tu' kintarang) and to the hell for the bad men (tu' kodi).

The cultural artifact (ornament) that is used in customary ritual consist of: a) the primary are absolutely needed in a customary ritual, b) the additional are used to add the sacred of a customary ritual, and c) The usual are unimporten things. The cultural ornaments such as the censer (sauk), the sacrifice (pa 'nganro), and the pipe betle ( $p a$ 'manang gallang) are absolutely presented in cenrtain customary ritual. The ornament such as drum (ganrang), fluite (pui'pui'), and small trumpet (basing)' $m$ the deth ritual (a'lajo-lajo) are also absoultely.

To add the sacred of the cultural ornament need old coin (dui' riolo) as prize (a'buang-buang) in appanganro ritual, one bounded paddy and some fruits (bua rappo) as a symbol of the poperity, the coconut shell kettle (sibo'bo'), the coconut shell mug (cimbokang or sai bulu), kemiri candel (ra 'rasa'), the brass tray (kappara') or rattan tray (kalili) as symbol of the simply live of the Kajang people.

Some cultural artefacts are considered unimportant in a ritual are the food (rice, side dish, banana, coffe etc.), bamboes lamp (sulo saju), small palm basket (tide or bantalang), the coconut leaf basket (kamboti), bitter palm wine (pakkacci), cooked flesh 
.ihara'), the white cooked nut (uttang hue), black ?:icky rice (kukusu') and so on. These all just used as liditing ornament in a customary ritual.

\section{Conclution}

The people of Kajang set Tu'rie 'A 'ra 'na as the "ighst level of cosmosses in their colosmology. He -: nsider the creator of this world and herited Pasang $\bullet$. Kajang as the only one guidance for him to solve "is live problems.

The people of Kajang still believes their ancestor "•elief system called sambajang tattapu and jenne' 'siluka (no ending worship and unseless ritual wash-

The important thing in this belief is the "cleaness", er the body or the spirit. The body cleaness can be done by ritual worship whereas the spirit clean is conmtly remaind to the God. There are three way to "^member God: remember when you are walking, are matting and you are going to sleep.

The customary ritual is the other way to worship .5 God. All of his customary ritual conduct just to ".onour his ancestors who are considered still live in ounding environement, include in Tanatowa (the . .itomary forest in Kajang).

\section{Foreword}

I would like to thank to my Great God cause of "is bless this resesarch can be finished in accordance th time shedulate.

Withouth any assistances from other this reaseach .an not be realized as it be. Therefore let me to thank :o my friends and colleagues Abd. Kadir, Hunaeni, Esty Pertiwiningsih, Abbas, Basri and Sari; to my key nfromant Puto Pallasa (Ammatowa of Kajang), to TI' causal informant Buton, Sampara, and Bombo, to Al-Qalam Journal staff Saprillah and his team who -as printed this article; to my sweet wife $\mathrm{Hj}$. Abidah Rauf, my lovely daughter Hanan Afifah and handsome roy Muhammad Alfa Roby who have given me support and suggestion to finish my research.

I also would like to thank to whomever has given ne his assistance but I could not appear his name in oage. Thank you very much and God will bless you all !nasya Allah.

\section{REFERENCES}

-Abu Hamid. 2003. Semangat Islam Dalam Kebudayaan Orang Bugis - Makassar Di Sulawesi Selatan. Makalah: Dibacakan Dalam Seminar Nasional Badan Pengembangan Kebudayaan Islam Kawasan Timur Indonesia Di Gorontalo Tahun 2003

Douglas Mary. 1966. Purity and Danger: An Analysis of Concept ofPupulation and Taboo. London : Rotledge \& Kegal Paul.

Durkheim E. 1964. The Elementary Forms of the Religious Life. London: Allen-Unwin.

Eliade M. 1959. The Sacred and The Frofane: The nature of Religion. New york: Harcourt, Brace/

Feuber Ludwig. 1957. The Essence of Christianity. New York: Harper.

Fraze G. J. 1976. The Golden Bough. London: MacMillan

Freud Sigmund. 1953. Introductory Lectures on Psychoanalysis. New York: Doubleday. 1978. The Future of an Illusion. London: Higarth Press.

Geertz, Clifford. 1992a. Tafsir Kebudayaan. Yogyakarta: Kanisius. 1992b. Kebudayaan dan Agama. Yogyakarta : Kanisius.

Gising Basrah. 2005. Manfaat Sistem Pengetahuan Lokal dalam Pengelolaan "Hutan Bprbasis Masyarakat" di Kawasan Hutan Adat Karampuang (Tesis). Makassar : Pascasarjana Unhas.

Haviland A. William. 1993. Antroplogi Budaya, Edisi Kempat, Jilid I dan 2. Jakarta : Erlangga.

JungC. 1938. 1938. The Psychology and Religion. New Haven: Yale University Press.

1972. Synchronicity, An Causal Connecting Principle. London: Rotladge \& Kegan Paul.

Koentjaraningrat. 1992: Beberapa Pokok Antropologi Sosial. Jakarta : Dian Rakyat.

McGuire B. Meredith. 1992. Relegion: The Soscial Context. Belmont, Califrnia: Wadsworth Inc.

Pals L. Daniel. 2001. Seven Theory ofRelgion: Dari Animisme E. B. Tylor, Materialisme Karl Marx Hingga Antropology Budaya Geerzt. Yogyakarta: Qalam.

Pitchard E. E. Evans. 1956. New Religion. New York : Oxford Universiti Press.

Sapiro M. E. 1966. Religion: Problems ofDefintion and Explanation, in Banton, ed. Nathropological Approaches to the Study of Religion. London

Tillich Paul. 1955. Theology and Symbolism. New York: Harver. Tylor E. B. 1913. The Primitive Culture. London: Murray

Weber Max. 1951. The Religion of China: Confusianism and Taoism, Transleted by H. H. Gerth, Glencoe, III. Free Press.

'_. 1958. The Religion of India: The Sociology of Hinduism and Budhism, Transleted by H. H. Gerth, Glencoe, III. Free Press. 